\title{
Assessment of Groundwater Quality in Saltaua Gopalpur Block of Basti District, (U.P.) India
}

\author{
R.V. PRASAD, D.R. TRIPATHI ${ }^{1}$ and VINOD KUMAR ${ }^{2}$ \\ 'Department of Chemistry, Kisan P.G. College Babhnan, Gonda (U.P.), India. \\ ${ }^{2}$ Department of Zoology, Kisan P.G. College B abhnan, Gonda (U.P.), India. \\ http://dx.doi.org/10.12944/CWE.8.3.20
}

(Received: August 08, 2013; Accepted: September 30, 2013)

\begin{abstract}
The present study was carried out to assess the ground water quality of various location of Saltaua Gopalpur block of Basti district during June-July 2013. Total 10 water samples were collected from hand pumps at different locations in and around Saltaua Gopalpur block. The water samples were analyzed for their physico-chemical characteristics, viz .pH, turbidity, chloride, total hardness, fluoride, nitrate, Iron and free chlorine. On comparing the results against water quality standards and standard values recommended by World Health Organization (WHO), it is found that most of the water samples are very hard and unsuitable for drinking purposes.
\end{abstract}

Key words: Ground water quality, Drinking water standards, Saltaua Gopalpur, Total hardness.

\section{INTRODUCTION}

Water is a one of the most important renewable natural resources. Approximately $71 \%$ of the earth's surface is covered with water. Fresh water is found as underground water in large reservoirs surrounded by rock called aquifers. This ground water has long been considered as one of the purest forms of water available in nature to meet the overall demand of rural and semi urban people'. In India most of the population is dependent on ground water as it is the only source of drinking water supply ${ }^{2}$. The quality of ground water is the resultant of all the processes and reaction that act on the water from the moment it condensed in the atmosphere to the time it is discharged by a well as spring and varies from place to place and with the depth of the water table ${ }^{3}$.

The groundwater is believed to comparatively cleaner and free from pollution than surface water ${ }^{2}$. But during last decade, it is observed that ground water gets polluted drastically because of increased human activities ${ }^{4-7}$. Consequently number of cases of water born diseases has been seen which are the causes of health hazards ${ }^{8-11}$. Therefore monitoring the quality of water is one of the essential issues of drinking water management ${ }^{12}$.

Considering the above aspects an attempt has been made under the present study to assess the physico-chemical properties of ground water in Saltaua Gopalpur block of Basti district.

\section{MATERIAL AND METHODS}

\section{Study Site}

Saltaua Gopalpur block is situated in the north part of the district Basti. It is $15 \mathrm{~km}$. away from the district head quarter. It has a geographical area of $216.90 \mathrm{~km}^{2}$, it is bounded by $26.81^{\circ} \mathrm{N}$ latitude and $82.76{ }^{\circ} \mathrm{E}$ longitude. The normal annual rain fall varies from $1050 \mathrm{~mm}$ to $1200 \mathrm{~mm}$. 


\section{Sample Collection}

A total 10 samples from different places which were minimum 2-3 $\mathrm{km}$ between one and another location was maintained in order to carry out a broad study on the quality of water in this area. The sample collection area has been assigned as sample points.

Table 1. Sampling places in the Saltaua Gopalpur Block.

\begin{tabular}{lll}
\hline S.No. & Sampling places & Site \\
\hline 1 & Aama & S1 \\
2 & Atara & S2 \\
3 & Baheriya & S3 \\
4 & Belhara & S4 \\
5 & Rehar Jungle & S5 \\
6 & Narayanpur & S6 \\
7 & Bhugania & S7 \\
8 & Saltaua Bazar & S \\
9 & Kanthui & S9 \\
10 & Saltaua Village & S10 \\
\hline
\end{tabular}

The sample was collected in plastic bottles which were cleaned with acid water, followed by rinsing twice with distilled water. The analysis of water was done by using Himedia water testing kit.

\section{RESULT AND DISCSSION}

The various physico-chemical parameters examined showed considerable variations in different samples. The observations are depicted in table-2.The findings and their comparison with $\mathrm{WHO}^{13}$ and $\mathrm{BIS}^{14}$ health based drinking guidlines are presented in table- 3 . The data revealed a considerable variation in the water samples with respect to their chemical composition.

$\mathrm{pH}$ is affected not only by the reaction of carbon dioxide but also by organic and inorganic solute present in water. Any alteration in water $\mathrm{pH}$ is accompanied by the change in other physicochemical parameters ${ }^{15}$.pH varies from 7.0 to 7.5. This shows that all samples are existed within the minimum and maximum tolerable limit of $\mathrm{WHO}$ and

Table 2 : Physico-Chemical quality of ground water of Saltaua Gopalpur Block.

\begin{tabular}{lcccccccccc}
\hline $\begin{array}{l}\text { Sampling Site } \rightarrow \\
\text { Parameters } \downarrow\end{array}$ & S1 & S2 & S3 & S4 & S5 & S6 & S7 & S8 & S9 & S10 \\
\hline $\mathrm{pH}$ & 7.1 & 7.0 & 7.1 & 7.1 & 7.5 & 7.3 & 7.2 & 7.0 & 7.2 & 7.1 \\
Turbidity (NTU) & 5 & 5 & 6 & 5 & 5 & 5 & 5 & 6 & 5 & 5 \\
Chloride (mg/lit). & 50 & 20 & 20 & 70 & 10 & 60 & 220 & 20 & 20 & 10 \\
Total Hard (mg/lit.) & 325 & 200 & 275 & 375 & 250 & 550 & 750 & 350 & 350 & 375 \\
Fluoride (mg/lit.) & 1.0 & 0.5 & 0.4 & 0.8 & 1.0 & 0.3 & 0.5 & 0.6 & 0.8 & 0.5 \\
Nitrate (mg/lit.) & 90 & 40 & 45 & 10 & 10 & 45 & 95 & 10 & 30 & 10 \\
Iron (mg/lit.) & 1.0 & 0.3 & 0.5 & 0.8 & 0.5 & 0.9 & 1.0 & 0.7 & 0.8 & 0.6 \\
Free Chlorine & Nil & Nil & Nil & Nil & Nil & Nil & Nil & Nil & Nil & Nil \\
\hline
\end{tabular}

Table 3 : Comparison of water with drinking water quality standards.

\begin{tabular}{llllllll}
\hline \multirow{2}{*}{$\begin{array}{l}\text { S. } \\
\text { No }\end{array}$} & Parameters & WHO & \multirow{2}{*}{ BIS } & \multicolumn{2}{c}{ Range } & \multirow{2}{*}{ Mean } & \multirow{2}{*}{ SD } \\
\cline { 5 - 6 } & & & Min. & Max. & & \\
\hline & pH & $6.5-8.5$ & $6.5-8.5$ & 7.0 & 7.5 & 7.16 & 0.15 \\
2 & Turbidity (NTU) & 5 & 5 & 5 & 6 & 5.2 & 0.42 \\
3 & Chloride (mg/lit.) & 250 & 250 & 10 & 220 & 50 & 63.42 \\
4 & Total Hardness (mg/lit.) & 300 & 300 & 200 & 750 & 3751 & 62.02 \\
5 & Nitrate (mg/lit.) & 50 & 45 & 10 & 95 & 38.5 & 32.06 \\
6 & Fluoride (mg/lit.) & 1.5 & 1.5 & 0.3 & 1.0 & 0.64 & 0.25 \\
7 & Iron (mg/lit.) & 0.3 & 0.3 & 0.3 & 1.0 & 0.71 & 0.23 \\
8 & Free Chlorine & - & - & Nil & Nil & - & - \\
\hline
\end{tabular}


BIS. The water samples were found to be slightly basic in nature ${ }^{16-18}$.

The turbidity varies from 5-6 NTU. This shows that most of the samples are existed within permissible limit of WHO \& BIS.

Chloride varies from $10-220 \mathrm{mg} / \mathrm{lit}$. All the water samples are under the permissible limits as of $\mathrm{WHO}^{19-20}$. Chloride is not harmful to human at low concentration but could alter the taste of water at concentration above $250 \mathrm{mg} / \mathrm{lit}^{21}$.

Hardness is very important in decreasing the toxic effect of poisonous element ${ }^{22}$. Hardness is measured in terms of total hardness and calcium hardness. Total hardness varies form 200-750 mg/ lit mostly exceeds the maximum permissible limits of $\mathrm{WHO}^{22-25}$. Hardness although has no health effects it can make water unsuitable for domestic and industrial use ${ }^{1}$.

Nitrate varies from 10-95 mg/lit. Although only two samples $\mathrm{S} 1$ and $\mathrm{S} 7$ exceeds the permissible limit and shows high concentration ${ }^{20}$. Nitrate indicates the pollution in ground water due to agricultural activities, sewage percolation beneath the surface ${ }^{22,26,27}$. Presence of nitrate in water indicates the final stage of mineralization ${ }^{28}$.

The major natural resource of fluoride is amphiboles, apatite, fluorite and mica. It's concentration in natural waters generally should not exceed $10 \mathrm{mg} / \mathrm{lit}^{1}$. The factor responsible for ground water contamination with fluoride are geological factors such as weathering of minerals, rock dissolution and decomposition. Containing fluoride over a long period of time resulting in the leaching it into ground water ${ }^{4}$. An anthropogenic factor such as industrial process liberates higher concentration of fluoride into atmosphere.

The concentration of fluoride in the studied water samples varies from 0.3 to $1.0 \mathrm{mg} / \mathrm{lit}^{20}$. High fluoride concentration causes dental fluorosis and more skeletal fluorosis ${ }^{29}$ whereas the low concentration or absence of fluoride in drinking water results in dental caries in children particularly when the fluoride concentration is less than 0.5 $\mathrm{mg} / \mathrm{lit}^{30}$.

The values of iron in study area varies from 0.3 to $1.0 \mathrm{mg} / \mathrm{lit}$. Which are higher than the tolerable value except sample S6. This may be due to soil origin and age old iron pipes used in the area ${ }^{16,31}$. The storage of iron causes a diseases called "anaemia" and prolonged consumption of drinking water with high concentration of iron may be lead to liver diseases called as haemosiderosis.

The free chlorine was found to be absent in all the samples.

\section{CONCLUSION}

The analysis of the physico-chemical parameters of ground water from ten different locations in Saltaua Gopalpur block shows that the $\mathrm{pH}$, turbidity, chloride and fluoride were within permissible limit. Highly exceeded value of total hardness, nitrate and iron were reported at some locations of study area. The observed standard deviation for the parameters shows that the deviation in the total hardness (162.02), chloride (63.42) and nitrate (32.06) are of moderately high range. From this it is concluded that various parameter concentration are varying highly in different location of Saltaua Gopalpur block.

\section{ACKNOWLEDGEMENTS}

The authors are thankful to Dr. Ram Prasad Ex-vice chancellor, Barkatullah University, Bhopal (M.P.), for providing academic inputs. Also thankful to Dr. T.A. Qureshi, (Ex.H.O.D) Deptt. Of Applied Aquaculture, Barkatullah, University, Bhopal, M.P. and to Prof. V.B. Upadhayay, D.D.U. Gorakhpur University, Gorakhpur (U.P. ), for their valuable suggestions. 


\section{REFERENCES}

1. Nirmala B., Suresh Kumar B.V., Suchetan P.A. and Shetprakash M., Seasonal variations of Physico -chemical characteristics of ground water sample of Mysore city, Karnataka, India. Int. J. Env.sci.,1(4),43-49, (2012).

2. Agrawal R, Physico -chemical analysis of some ground water samples of Kotputil town Jaipur, Rajasthan. Int. J.che. Env. Pharm. Res., Rajasthan, 2,111-113, (2010).

3. Shyamala R., Santhi M. and Lalitha P., Physico-chemical analysis of borewell water samples of elungupalayam area in Coimbatore District, Tamilnadu, India. E.J. Chemistry, 5(4), 924-927 (2008).

4. Jamal A.A., Physico-chemical studies in Uyyakondan channel water of river Cavery., Poll. Res.,17(2),111 (1998).

5. Murhekar G.H., Determination of physic chemical parameters of surface water sample in and around Akot city, Int. J. Res. chem. Env. 1(2), 183-187 (2011).

6. Singh V.,Physico-chemical examination of water, sewage and Industrial effluents, Res.J.Chem.and Env.10(3), 62-66 (2006).

7. Mishra A. and Bhatt V., Physico-chemical and Microbiological analysis of under ground water in V.V. Nagar and Nearby Places of Anand District, Gujarat, India. E-J chem., 5(3), 487-492 (2008).

8. Desi P.V., water auality of Dudhsagar river at Dudhasagar, Goa,India. Poll.Res., 4,377-382 (1995).

9. Elizabeth K.M.and Naik P.L.,Effect of polluted water on human health, Poll.Res., 24(2), 337 (2005).

10. Muller E.E, Ethlers M.M. and Grabow, The occurrence of E. coli. 0157:H7 in South Africa water sources intended for direct and indirect human consumption, water Res., 35, 30853088 (2001).

11. Aremu M.O., Gav,B.L., Opaluwa O.D., Atolaiya B.O., Madu P.C. and Sangari D.U., Assessment of physico-chemical contaminants in waters and Fishes from selected rivers in Nasarawa State, Nigeria. Res. J.Chem. Sci., 4, 6-17 (2011).

12. Shama S., Iffat N., Mohammad I.A.and Safia A., Monitoring of physic -chemical and microbiological analysis of under ground water sample of district Kallar Syedan, Rawalpindi-Pakistan. Res. J.Chemi.Sci.,1 (8), 24-30 (2011).

13. WHO, International Standard for drinking water, 3rd ed, Geneva, (2008).

14. BIS, Specification for drinking water. Bureau of Indian Standards, New Delhi, 171-178

15. Wetzel R.G., Limnology, W.B. Saunders Co.,Philadelphia. USA, 743 (1975).

16. Behra B., Das M. and Rana G.S., Studies on ground water pollution due to iron content and water quality in and around Jagdalpur, Bustar District, Chattisgarh, India. J. chem. Pharma Res.,4(8),3803-3807 (2012).

17. Dharmaraja J., Vadivel S. and Ganesh Karthick E., Physico -chemical analysis of ground water samples of selected district of Tamilnadu and Kerala. Int.J. Scint. Tech. Res, 1(5). 92-95 (2012).

18. Parihar S.S., Kumar A., Kumar A., Gupta R.N., Pathak M., Shrivastav A. and Pandey A.C., Physico-chemical and microbiological analysis of under ground water in and around Gwalior city., M.P., India. Res.J.Recent sci.,1(6),62-65 (2012).

19. Bundela P.S.,Sharma. A,Pandey A.K., Pandey P. and Awasthi A.K., Physicochemical analysis of ground water near municipal solid waste dumping sites in Jabalpur, M.P.India. Int,J. Plant, animal Env. Sci. 2(1), 217-222 (2012).

20. Arya S., Kumar V., Minakshi and Dhaka A., Assessment of underground water quality : A case study.of Jhansi city,U.P.India. Int. Multidis.. Res.J.,1(7),11-14 (2011).

21. Hauser B.A., Drinking water chemistry : A Laboratory manual. Lewis Publishers, A CRC Press company : Boca Raton, FL.,71(2001).

22. Rajankar P.N, Wate S.R., Tambekar D.H. and Gulhane. S.R., Assessment of ground Water Quality using water auality Index (WQI) in wardha district. J. Env. Sci. sustaina., 1(2), 49-54 (2013).

23. Meenakshi, Garg V.K, Kavita, Renuka and Malik A., Ground water quality in some villages of Haryana, India : focus on fluoride 
and fluorosis. J. Hazar. Mater,106B, 85-97 (2004).

24. Veeraputhiran V. and Alagumuthu G., A report on fluoride distribution in drinking water, Int.J. Env.Sci., 1(4), 558-566 (2010).

25. Poonam, Kumar R. and Yadav A., Ground water quality in Mohenderagarh Town, Haryana, India. Int.J. Pharm. Chem.Sci, 2(1), 226-228 (2013).

26. Jawad A, Shereideh A.L., Abu S.A., Rukah. Y.and Al Qadat K., Aquifer ground water quality. Science of the total Environment, 128 , 69-81 (1998).

27. Taiwo A.M., Adeogn A.O., Olatunde K.A. and Adegbite K.I., Analysis of ground water quality of hand dug wells in peri-urban area of Obantoko, Abeokuta for selected physic chemical parameters. Pecific J. Sci Tech., 12 (1) $527-534$ (2011).
28. Nema P., Rajgopalan S. and Mehta C.G., Quality and treatment of Sabarmati river water Ahmedabad, J.I.W.W.A., 16(1), 99-107 (1984).

29. Ravindra K. and Garg V.K., Appraisal of ground water quality for drinking purpose in Hisar city (India) with special reference to fluoride. Int. J. Env. HIt. Res, in press (2005).

30. Patil N., Ahmed A., Sureshbabu H., Kottureshwar N.M., Jayashree M. and Nijalingappa J., Study on the physico chemical characteristics of ground water of Gulbarga city, Karnataka, India. Int.J. Appli. Biopharm. Tech., 1(2), 518-523 (2010).

31. Rajgopal, Ground water quality assessment for public policy in India. 1st annual report, Deptt. of Geography, IOWA University, IOWA, 10-11 (1984). 